\title{
Glosa częściowo krytyczna do wyroku Sądu Najwyższego - Izby Cywilnej z dnia 25 września 2019 r., III CSK 217/17
}

\author{
A partially critical commentary on judgement of the Supreme Court - \\ Civil Chamber of 25 September 2019, III CSK 217/17 \\ Частично критический комментарий к решению Гражданской коллегии \\ Верховного Суда от 25 сентября 2019 года, III CSK 217/17
}

\author{
SABINA POCHOPIEŃ \\ Dr, Uniwersytet Wrocławski \\ e-mail: sabina.pochopien@uwr.edu.pl, https://orcid.org/0000-0001-5505-6077
}

\begin{abstract}
Streszczenie: Komentowane orzeczenie dotyczy rozkładu ciężaru dowodu w postępowaniu cywilnym wytoczonym przeciwko byłemu pracownikowi w związku z zarzutem ujawnienia tajemnicy przedsiębiorstwa. Zdaniem Sądu Najwyższego to pracownik powinien wykazać, że w podjętej działalności gospodarczej nie wykorzystuje przysługującej byłemu pracodawcy tajemnicy przedsiębiorstwa. Pogląd ten należy ocenić krytycznie. Natomiast na pozytywną ocenę zasługują rozważania sądu dotyczące relacji pomiędzy zakazem konkurencji a obowiązkiem zachowania tajemnicy przedsiębiorstwa oraz zakresu stosowania wobec pracowników obowiązującego przed dniem 4 września 2018 r. czasowego ograniczenia obowiązku poufności.
\end{abstract}

Słowa kluczowe: ciężar dowodu, tajemnica przedsiębiorstwa, czyn nieuczciwej konkurencji, były pracownik

Summary: The commented judgement concerns the burden of proof in the civil procedure against a former employee accused of revealing a business secret. In Supreme Court, opinion employee should prove that in his business activity does not make use of former employer business secrets. This opinion should not be accepted. On the other hand, the court's opinion concerning the relation between the prohibition on competition and duty of respecting business secret, as well as the scope of application to the employee's time limitation regarding confidentiality, which was enforced before the 4th of September 2018, should be approved.

Key words: burden of proof, business secret, act of unfair competition, former employee

Резюме: Комментируемое решение касается распределения бремени доказывания в гражданском процессе, возбужденном против бывшего сотрудника в связи с его обвинением в разглашении коммерческой тайны. По мнению Верховного суда, именно сотрудник должен доказать, что в ходе предпринятой деятельности он не использует коммерческую тайну, на которую имел право бывший работодатель. Это мнение следует оценивать критически. С другой стороны, положительной оценки заслуживают соображения суда относительно взаимосвязи между запретом на конкуренцию и обязательством хранить коммерческую тайну компании, а также относительно сферы применения к сотрудникам временного ограничения обязательства о конфиденциальности, действовавшего до 4 сентября 2018 года.

Ключевые слова: бремя доказывания, коммерческая тайна, акт недобросовестной конкуренции, бывший сотрудник 


\section{Wstęp}

Komentowane orzeczenie dotyczy zagadnienia rozkładu ciężaru dowodu w postępowaniu cywilnym zainicjowanym w związku z zarzutem ujawnienia przez byłego pracownika tajemnicy przedsiębiorstwa. Sąd Najwyższy stwierdza w nim, że to na pracowniku spoczywa ciężar wykazania, że w ramach podjętej działalności gospodarczej nie wykorzystuje tajemnicy przedsiębiorstwa przysługującej byłemu pracodawcy. Celem opracowania jest wykazanie, że w świetle obowiązujących przepisów prawa pogląd ten należy ocenić krytycznie. Na pełną akceptację zasługuje natomiast stanowisko sądu postulujące rozgraniczenie instytucji zakazu konkurencji oraz powinności zachowania tajemnicy przedsiębiorstwa. Aprobująco należy ocenić ponadto wyartykułowany w orzeczeniu pogląd, zgodnie z którym wynikające z art. 11 ust. 2 ustawy z dnia 16 kwietnia 1993 r. o zwalczaniu nieuczciwej konkurencji ${ }^{1}$, w brzmieniu sprzed nowelizacji dokonanej w dniu 5 lipca 2018 r., ograniczenie obowiązku zachowania tajemnicy przedsiębiorstwa w stosunku do pracowników co do zasady do 3 lat od dnia ustania stosunku pracy obejmuje wyłącznie informacje pozyskane w związku z wykonywaniem obowiązków pracowniczych.

\section{Stan faktyczny}

Stan faktyczny komentowanej sprawy przedstawia się następująco. Stronę powodową N. spółkę z ograniczoną odpowiedzialnością z siedzibą w K. (zwaną dalej pracodawcą) łączyła z pozwaną B.B. (zwaną dalej pracownicą) umowa o pracę od dnia 14 grudnia 2007 r. Zatrudnienie było początkowo realizowane na stanowisku edytora, następnie menadżera do spraw zarządzania projektami oraz obsługi klientów kluczowych, w końcu na stanowisku menadżera operacyjnego. Pracownica w czasie trwania stosunku pracy oraz w okresie jednego roku od jego rozwiązania lub wygaśnięcia zobowiązana była do zachowania tajemnicy przedsiębiorstwa swojego pracodawcy. Przekazywanie, ujawnianie, wykorzystywanie, zbywanie albo oferowanie zbycia informacji podlegających takiej kwalifikacji mogło nastąpić dopiero po uprzednim, pisemnym zezwoleniu zarządu. Natomiast w przypadku usta-

1 Tekst jednolity: Dz. U. z 2018 r. poz. 419. Do analizowanego stanu faktycznego znajduje zastosowanie art. 11 ustawy o zwalczaniu nieuczciwej konkurencji w brzmieniu sprzed nowelizacji dokonanej $\mathrm{w}$ dniu 5 lipca $2018 \mathrm{r}$. 
nia stosunku pracy pracownica zobowiązała się najpóźniej w dniu jego rozwiązania lub wygaśnięcia dokonać zwrotu wszelkich dokumentów i materiałów dotyczących tajemnicy pracodawcy, jakie sporządziła, opracowała lub otrzymała w czasie trwania umowy albo w związku lub przy okazji jej wykonywania.

W dniu 9 kwietnia 2013 r. pracodawca reprezentowany przez pracownicę zawarł ze swoim kontrahentem G.AB z siedzibą w S. umowę, na podstawie której zobowiązał się do świadczenia usług w dziedzinie marketingu i komunikacji. W sierpniu 2013 r. pracownica uzyskała od jego jedynego wspólnika informację, że zamierza zakończyć współpracę z jej pracodawcą i założyć spółkę, która przejmie jego rolę. Wymiana korespondencji dotyczącej wskazanej kwestii rozpoczęła się w dniu 9 lutego 2014 r., a jej rezultatem było rozwiązanie przez pracownicę łączącej ją z pracodawcą umowy o pracę na mocy porozumienia stron w dniu 28 lutego 2014 r. Następnie kontrahent pracodawcy zawarł z pracownicą umowę pożyczki środków pieniężnych, co umożliwiło jej zawiązanie w dniu 21 marca 2014 r. spółki z ograniczoną odpowiedzialnością zajmującej się świadczeniem usług komunikacyjnych.

W odpowiedzi na powyższe działania pracodawca wystąpił przeciwko byłej pracownicy i założonej przez nią spółce z roszczeniami o: 1) zaniechanie świadczenia usług doradztwa z zakresu marketingu i komunikacji na rzecz jego byłego kontrahenta, 2) zobowiązanie do opublikowania oświadczenia o przeproszeniu za nielegalne wykorzystywanie tajemnicy przedsiębiorstwa i sprzeczne z prawem i dobrymi obyczajami przejęcie klienta, 3) zasądzenie odszkodowania za naruszenie tajemnicy przedsiębiorstwa i za sprzeczne z prawem i dobrymi obyczajami przejęcie klienta, a także 4) zasądzenie od pozwanej spółki bezpodstawnie uzyskanych korzyści.

\section{Stanowisko Sądu Okręgowego oraz Sądu Apelacyjnego}

Sąd Okręgowy oddalając powództwo o nakazanie zaniechania naruszeń, uzasadnił swoje rozstrzygnięcie faktem wniesienia pozwu po ustaniu obarczającego pracownicę obowiązku poufności. Zauważył ponadto, że zawiązana przez nią spółka informacje kwalifikowane przez pracodawcę jako tajemnica przedsiębiorstwa mogła uzyskać od pracownicy bądź przejętego przez nią kontrahenta, który mógł poznać je w czasie własnych kontaktów z pracodawcą. Zdaniem sądu w tym zakresie wskazane informacje nie stanowiły tajemnicy przedsiębiorstwa pracodawcy, lecz jego kontrahenta. Oddalenie powództwa w zakresie roszczeń pieniężnych wynikało na- 
tomiast $\mathrm{z}$ faktu, że przyczynę zaprzestania przez kontrahenta pracodawcy współpracy z nim stanowił konflikt pomiędzy właścicielami wskazanych spółek, a nie działania pozwanych.

Sąd Apelacyjny oddalił apelację pracodawcy, podzielając ustalenia faktyczne i prawne sądu pierwszej instancji. Podkreślił ponadto, że pełnienie przez pracownicę funkcji prokurenta pracodawcy pozostawało bez wpływu na okres związania wynikającym z umowy obowiązkiem poufności. W związku z powierzaniem pracownicy nowych zadań strony dokonywały w niej zmian, nie decydując się jednak na modyfikację czasu, na który została ustanowiona charakteryzowana powinność.

\section{Stanowisko Sądu Najwyższego}

W związku z wniesieniem przez pracodawcę skargi kasacyjnej doszło do wydania wyroku przez Sąd Najwyższy. Stwierdzono w nim, że zarzucenie przez pracodawcę byłemu pracownikowi, iż w okresie wskazanym w umowie o pracę naruszył tajemnicę jego przedsiębiorstwa, o ile wykaże on, że określone informacje odpowiadają definicji zawartej w treści art. 11 ust. 4 ustawy o zwalczaniu nieuczciwej konkurencji, skutkuje przerzuceniem na byłego pracownika ciężaru dowodu, iż ujawnione informacje nie stanowiły tajemnicy przedsiębiorstwa w rozumieniu wskazanego przepisu, względnie że utworzone przez byłego pracownika przedsiębiorstwo zostało zorganizowane na nowych zasadach - w stosunku do tych stosowanych przez przedsiębiorcę domagającego się ochrony - wypracowanych w wyniku wiedzy i doświadczenia zawodowego tego pracownika. Incydentalnie podjęto w nim także rozważania dotyczące relacji pomiędzy instytucją zakazu konkurencji a obowiązkiem zachowania tajemnicy przedsiębiorstwa oraz zagadnienie zakresu stosowania wynikającego z treści art. 11 ust. 2 ustawy o zwalczaniu nieuczciwej konkurencji ograniczenia czasowego obowiązku zachowania tajemnicy przedsiębiorstwa w odniesieniu do osób uprzednio zatrudnionych przez przedsiębiorcę.

\section{Komentarz}

Przechodząc do pierwszego z sygnalizowanych zagadnień, należy podkreślić okoliczność, że ustawa o zwalczaniu nieuczciwej konkurencji co do zasady przyjmuje regułę dotyczącą rozkładu ciężaru dowodu wyrażoną w treści art. 6 Kodeksu cy- 
wilnego ${ }^{2}$. Zgodnie ze wskazanym przepisem ciężar udowodnienia faktu spoczywa na osobie, która z faktu tego wywodzi skutki prawne. Jak wskazuje T. Sokołowski, wskazany przepis ustanawia ogólną zasadę rozkładu dowodu, od której wyjątki ustanawiać mogą przepisy szczególne ${ }^{3}$. Na gruncie ustawy o zwalczaniu nieuczciwej konkurencji regulacja taka została zawarta w treści art. 18a i dotyczy czynu nieuczciwej konkurencji, polegającego na wprowadzaniu w błąd. Przepis ten stanowi bowiem, że ciężar dowodu prawdziwości oznaczeń lub informacji umieszczanych na towarach albo ich opakowaniach lub wypowiedzi zawartych w reklamie spoczywa na osobie, której zarzuca się czyn nieuczciwej konkurencji związany z wprowadzaniem w błąd. Zarówno jednak w literaturze przedmiotu ${ }^{4}$, jak i orzecznictwie ${ }^{5}$ podkreśla się konieczność jego ścisłej wykładni. Jak wskazał Sąd Apelacyjny w Warszawie w wyroku $\mathrm{z}$ dnia 6 grudnia 2007 r. ${ }^{6}$, choć zgodnie $\mathrm{z}$ art. 18a ustawy o zwalczaniu nieuczciwej konkurencji ciężar dowodu prawdziwości oznaczeń lub informacji zamieszczonych na towarach spoczywa na osobie, której zarzuca się popełnienie deliktu wprowadzenia w błąd, nie oznacza to jednak, że na powodzie nie spoczywa obowiązek wykazania okoliczności, stanowiących podstawę faktyczną powództwa stosownie do reguły ogólnej wynikającej z treści art. 6 K.c.

Podkreślenia wymaga fakt, że istnieje ponadto grupa przepisów zmieniających rozkład ciężaru dowodu poprzez nałożenie go na stronę kwestionującą istnienie faktu prawnego. W pierwszej kolejności należy zaliczyć do niej domniemania prawne. Kategoria ta ma charakter zbiorczy, gdyż obejmuje swoim zakresem domniemania materialne, czyli normy nakazujące przyjęcie określonego wniosku $\mathrm{w}$ razie stwierdzenia zaistniałej $\mathrm{w}$ przepisie przesłanki zwanej podstawą domniemania (np. art. 9, art. 339 i 340 K.c.) oraz domniemania formalne będące normami nakazującymi bezwarunkowe uznanie określonych twierdzeń (art. 7 K.c.). Zmianie rozkładu ciężaru dowodu służą także przepisy prawne nakazujące uznanie jakiegoś faktu „w razie wątpliwości” (np. art. 70 czy 71 K.c.) oraz te posługujące się zwrotem

2 Ustawa z dnia 23 kwietnia 1964 r. - Kodeks cywilny, tekst jednolity: Dz. U. z 2020 r. poz. 1740 (dalej: K.c.).

3 T. Sokołowski, w: Kodeks cywilny. Komentarz, t. 1. Czesść ogólna, red. A. Kidyba, 2012 [baza danych LEX], Komentarz do art. 6, teza 1. Szerzej na temat problematyki rozkładu ciężaru dowodu zob. I. Adrych-Brzezińska, Ciężar dowodu w prawie i procesie cywilnym, Warszawa 2015, s. 145-240; A. Tyc, Ciężar dowodu - wokót definicji oraz dopuszczalności umownej regulacji, Zeszyt Studencki Kół Naukowych Wydziału Prawa i Administracji UAM 2012, nr 2, s. 199-208; K. Piasecki, System dowodów i postępowanie dowodowe w sprawach cywilnych, 2012 [baza danych LEX], Rozdział piąty. Rozkład ciężaru dowodu w sprawach cywilnych.

4 J. Szwaja, K. Jasińska, w: Ustawa o zwalczaniu nieuczciwej konkurencji. Komentarz, red. J. Szwaja, 2019 [baza danych Legalis], Komentarz do art. 18a, teza 2.

5 Wyrok SA w Poznaniu z dnia 12 grudnia 2013 roku, I Aca 958/13, Legalis nr 775901.

6 Wyrok SA w Warszawie z dnia 6 grudnia 2007 roku, I ACa 1037/07, niepubl. 
„chyba, że”. Ostatnia z wyróżnionych kategorii wprowadza odstępstwo od reguły ogólnej, której istota polega na tym, że niektóre elementy hipotezy normy prawnej nie wymagają udowodnienia, a jej adresat musi wykazać, że dany fakt objęty hipotezą normy nie zaistniał (np. art. $83 \$ 2$ czy art. $169 \$ 1$ K.c.) $)^{7}$. Podkreślenia wymaga jednak fakt, że art. 11 ustawy o zwalczaniu nieuczciwej konkurencji nie posługuje się żadną ze wskazanych konstrukcji.

Należy zauważyć, że przerzucenie na byłego pracownika ciężaru wykazania, że w podjętej działalności nie wykorzystuje informacji stanowiących tajemnicę przedsiębiorstwa byłego pracodawcy, może prowadzić do skutków nieakceptowalnych z punktu widzenia podstawowych celów i funkcji procesu cywilnego. Tak korzystne ukształtowanie sytuacji procesowej powoda, polegające na ograniczeniu jego roli do wykazania, że potencjalnie naruszona informacja odpowiada definicji legalnej tajemnicy przedsiębiorstwa, niejednokrotnie może rodzić po stronie byłych pracodawców pokusę występowania $\mathrm{z}$ bezpodstawnymi powództwami w celu nadszarpnięcia renomy i kondycji finansowej konkurenta rozpoczynającego dopiero swoją działalność poprzez wikłanie go w długotrwały i kosztowny proces sądowy.

Brak przepisu prawnego, który w przypadku deliktu nieuczciwej konkurencji określonego w treści art. 11 ustawy o zwalczaniu nieuczciwej konkurencji ustanawiałby zmianę rozkładu ciężaru dowodu, powoduje konieczność zastosowania normy wyrażonej w treści art. 6 K.c. Jak zauważa A. Michalak, przedsiębiorca dochodzący roszczeń na gruncie ustawy o zwalczaniu nieuczciwej konkurencji będzie musiał wykazać, że informacja, której ochrony się domaga, stanowi tajemnicę przedsiębiorstwa, podjął niezbędne działania w celu zachowania jej poufności, a osoba, przeciwko której żądania są kierowane, niezgodnie z prawem lub dobrymi obyczajami wykorzystała tę informację. Autor ten zauważa jednak, że wykazanie ostatniej przesłanki wymaga niejako złapania sprawcy na gorącym uczynku, w związku z czym pracodawca niejednokrotnie nie dysponuje bezpośrednim dowodem wskazującym na przejęcie tajemnicy ${ }^{8}$. Powyższe trudności natury dowodowej nie uprawniają jednak sądu orzekającego do arbitralnej zmiany reguły rozkładu ciężaru dowodu.

Potencjalny środek umożliwiający przezwyciężenie sygnalizowanych trudności dowodowych w konkretnym stanie faktycznym zdają się prima facie stanowić domniemania faktyczne. Ich istota nie polega bowiem na zmianie rozkładu ciężaru dowodu, a więc przeniesieniu go na przeciwnika, lecz na umożliwieniu

7 P. Machnikowski, w: Kodeks cywilny. Komentarz, red. E. Gniewek, P. Machnikowski, 2019 [baza danych Legalis], Komentarz do art. 6, teza 2.

8 A. Michalak, w: Ustawa o zwalczaniu nieuczciwej konkurencji. Komentarz, red. M. Sieradzka, M. Zdyb, 2016 [baza danych LEX], Komentarz do art. 11, teza 50. 
dowodzenia faktów na podstawie wniosków wynikających z innych ustalonych faktów w oparciu o zasady logicznego myślenia i doświadczenie życiowe $e^{9}$. Jednakże ich stosowanie w celu uniknięcia potrzeby wykazania stanowiącej o istocie deliktu określonego w treści art. 11 ustawy o zwalczaniu nieuczciwej konkurencji okoliczności przekazania, ujawnienia lub wykorzystania cudzych informacji stanowiących tajemnicę przedsiębiorstwa wywołuje znaczne wątpliwości. W pierwszej kolejności należy zauważyć, że stosowanie analizowanej konstrukcji obarczone jest znacznym ryzykiem. Jak wskazał Sąd Najwyższy w wyroku z dnia 30 marca $2000 \mathrm{r}^{10}$, domniemanie faktyczne będące rozumowaniem sędziego opartym na wiedzy i doświadczeniu może zostać wzruszone przez wykazanie nieprawidłowości takiego rozumowania. Taka nieprawidłowość może polegać na tym, że fakt przyjęty przez sąd za podstawę wnioskowania o innym fakcie nie został ustalony bądź też na tym, że fakty przyjęte za podstawę domniemania faktycznego nie uzasadniają, w świetle wiedzy i doświadczenia życiowego, wyprowadzonego z niej wniosku $^{11}$. Należy uznać, że samo podjęcie przez byłego pracownika działalności gospodarczej odpowiadającej pod względem przedmiotowym tej prowadzonej przez byłego pracodawcę nie stanowi dostatecznej podstawy dla uznania, że w jej ramach dochodzi do wykorzystania tajemnicy przedsiębiorstwa byłego pracodawcy. Powyższe założenie prowadziłoby bowiem do nieuzasadnionego ograniczenia wynikającej z treści art. 20 Konstytucji Rzeczypospolitej Polskiej ${ }^{12}$ wolności działalności gospodarczej, zwłaszcza że były pracownik decydując się na uzyskanie statusu przedsiębiorcy, zwykle podejmuje działalność pokrywającą się pod względem przedmiotowym z tą prowadzoną przez byłego pracodawcę. Skoro do niej ogranicza się wiedza i doświadczenie pracownika zdobyte w czasie zatrudnienia u danego przedsiębiorcy, zachowanie takie należy uznać za uzasadnione racjonalnymi względami. W związku z powyższym należy uznać, że na pełną aprobatę zasługuje stanowisko wyrażone przez Sąd Apelacyjny w Poznaniu w wyroku z dnia 24 listopada 2010 r. ${ }^{13}$, w którym stwierdził, że z faktu podjęcia przez byłego pracownika działalności konkurencyjnej, obejmującej czynności analogiczne do tych wykonywanych podczas zatrudnienia, nie wynikają żadne działające na korzyść byłego pracodawcy domniemania, zwalniające $\mathrm{z}$ obowiązku dowodzenia wypełnienia

9 M. Rejdak, w: Kodeks postępowania cywilnego, t. 2. Komentarz. Art. 205 (1) - 424 (12), red. A. Marciniak, 2019 [baza danych Legalis], Komentarz do art. 231, teza 1 i 2.

10 Wyrok SN z dnia 30 marca 2000 r., III CKN 811/98, Legalis nr 362265.

11 Tamże.

12 Konstytucja Rzeczypospolitej Polskiej z dnia 2 kwietnia 1997 r., tekst jednolity: Dz. U. z 1997 r. Nr 78 , poz. 483 z późn. zm.

13 Wyrok SA w Poznaniu z dnia 24 listopada 2010 r., I ACa 887/10, LEX nr 898663. 
przez pracownika hipotez norm zawartych w art. 11 ust. 1, 2 i 4 ustawy o zwalczaniu nieuczciwej konkurencji. Zaakceptowanie wniosku przeciwnego powoduje przyjęcie domniemania wykorzystania tajemnicy przedsiębiorstwa w podjętej po ustaniu stosunku pracy działalności gospodarczej pokrywającej się przedmiotowo $\mathrm{z}$ tą prowadzoną przez byłego pracodawcę, a więc uznanie, że w Polsce, podobnie jak w Stanach Zjednoczonych, obowiązuje doktryna nieuniknionego ujawnienia. Jej istota polega na przyjęciu założenia, że pracownik podejmujący nową pracę na takim samym lub zbliżonym stanowisku z konieczności musi naruszyć tajemnicę poprzedniego pracodawcy ${ }^{14}$. Przeniesienie charakteryzowanej konstrukcji na grunt rodzimego porządku prawnego, będącego przykładem systemu kontynentalnego, należy jednak uznać za niedopuszczalne. Wynika to z faktu, że nie znajduje ona oparcia w obowiązujących przepisach prawnych. Ze względu na okoliczność, że Konstytucja Rzeczypospolitej Polskiej gwarantuje w treści art. 65 wolność wyboru miejsca pracy, wszelkie ograniczenia w tym zakresie powinny mieć oparcie w konkretnych regulacjach prawnych.

Przyjęcie charakteryzowanej konstrukcji rodzi ponadto pytanie o celowość zawierania umów o zakazie konkurencji po ustaniu stosunku pracy, o których mowa w treści art. 101 (2) Kodeksu pracy ${ }^{15}$. Skoro bowiem pracodawca mógłby powoływać się na owo „domniemanie bezprawności” i formułować wobec pracownika roszczenia określone w ustawie o zwalczaniu nieuczciwej konkurencji, w tym również te mające charakter odszkodowawczy, zawieranie klauzuli konkurencyjnej z przyczyn finansowych traciłoby rację bytu. Jak bowiem wynika z lektury treści art. 101 (2) K.p., nałożenie na byłego pracownika zobowiązania powstrzymywania się od działalności konkurencyjnej rodzi po stronie byłego pracodawcy konieczność wypłaty odszkodowania.

W związku z powyższym należy zachować dalece idącą ostrożność w posługiwaniu się domniemaniami faktycznymi dla ustalenia faktu naruszenia tajemnicy przedsiębiorstwa. Natomiast w odróżnieniu od arbitralnej zmiany przez sąd reguły rozkładu ciężaru dowodu przewidzianej w treści art. 6 K.c. stosowanie analizowanego mechanizmu należy dopuścić w konkretnych sprawach ze względu na specyfikę określonego stanu faktycznego. Wydaje się, że w przypadku, gdy proces produkcji określonego urządzenia został podzielony na etapy i każdy pracownik w nim uczestniczący jest zaznajomiony wyłącznie z rozwiązaniami technicznymi mającymi znaczenie dla konkretnej fazy produkcji, to podjęcie przez byłego

14 A. Michalak, Ochrona tajemnicy przedsiębiorstwa. Zagadnienia cywilnoprawne, Kraków 2006, s. 84 za D. Pasqualone, Intellectual Property: Globespan, Inc v. O’Neil, Berkeley Technology Law Journal 2002, nr 1, s. 251. 
pracownika zatrudnienia u konkurencyjnego przedsiębiorcy oraz niezwłoczne rozpoczęcie przez tego ostatniego produkcji i sprzedaży produktu uosabiającego takie rozwiązanie należy uznać za okoliczność uprawniającą sąd do uznania za udowodniony fakt przekazania tajemnicy przedsiębiorstwa w szczególności, jeżeli pierwszy z przedsiębiorców nie rozpoczął jeszcze sprzedaży swoich produktów. Ostatnia z okoliczności charakteryzujących wykreowany stan faktyczny ma doniosłe znaczenie, gdyż uniemożliwia podniesienie zarzutu, że nowy pracodawca posłużył się mechanizmem reverse engineering, a więc przez analizę produktu dostępnego już na rynku poznał mechanizmy, które on uosabia.

Należy jednak uznać, że analizowana konstrukcja nie powinna znaleźć zastosowania w stanie faktycznym będącym przedmiotem glosowanego orzeczenia ze względu na niejednoznaczność okoliczności sprawy. Sąd Najwyższy w treści uzasadnienia uznał za znamienne, że: „spółka G. po faktycznym zerwaniu współpracy ze stroną powodową nie podjęła działań $w$ celu skorzystania $z$ usług innego podmiotu funkcjonującego na rynku, lecz w porozumieniu z pozwaną B.B., jeszcze w okresie jej zatrudnienia u strony powodowej, przystąpiła do tworzenia spółki”. Pracodawca podniósł natomiast $\mathrm{w}$ pozwie, że pozyskanie $\mathrm{w}$ tak krótkim czasie przez utworzoną spółkę kontraktu zapewniającego stabilność finansową nie byłoby możliwe bez wykorzystania wypracowanej przez niego tajemnicy przedsiębiorstwa. Pogląd ten nie zasługuje jednak na aprobatę. Należy bowiem zauważyć, że działalność pracownicy mogła opierać się na nowych w stosunku do byłego pracodawcy zasadach wypracowanych w wyniku jej wiedzy i doświadczenia, a pewne jej szczególne właściwości i zdolności mogły stanowić asumpt dla kontrahenta pracodawcy do nawiązania z nią współpracy. Jak słusznie zauważa T. Kuczyński, należy dokonać rozróżnienia między tajemnicą przedsiębiorstwa a wiedzą, doświadczeniem i umiejętnościami pracownika nabytymi w trakcie realizowania zatrudnienia. Druga z wyróżnionych kategorii nie korzysta bowiem z ustawowej ochrony, o ile strony stosunku pracy nie zawarły porozumienia ograniczającego posługiwanie się taką wiedzą $\mathrm{w}$ celach konkurencyjnych po ustaniu zatrudnienia ${ }^{16}$. Pogląd taki podzielają ponadto S. Sołtysiński i S. Gogulski, którzy wskazują, że za wyłączeniem z zakresu tajemnicy przedsiębiorstwa indywidualnych umiejętności i doświadczenia osób fizycznych przemawia postulat zapewnienia mobilności na rynku pracy. Zdaniem wskazanych autorów zagwarantowanie pracownikom możliwości wykorzystania w nowych miejscach pracy wcześniej zdobytych doświadczeń leży w interesie publicznym. Kwestia ta została także podkreślona w motywach 14 i 21 preambuły oraz art. 1 ust. 3 lit. b dyrektywy Parlamentu

T. Kuczyński, Nieuczciwa konkurencja jako kategoria prawa pracy, Przegląd Sądowy 1994, nr 4, s. 25. 
Europejskiego i Rady (UE) 2016/943 ${ }^{17} \mathrm{z}$ dnia 8 czerwca 2016 r. w sprawie ochrony niejawnego know-how i niejawnych informacji handlowych (tajemnic przedsiębiorstwa) przed ich bezprawnym pozyskaniem, wykorzystaniem i ujawnieniem ${ }^{18}$.

Na zasadność prezentowanego poglądu nie wpływa okoliczność, że pracownica wbrew swojemu zobowiązaniu zwróciła komputer służbowy dopiero w dzień po ustaniu stosunku pracy po uprzednim usunięciu znajdujących się na nim materiałów. Takie zachowanie stanowi co prawda naruszenie zobowiązania umownego pracownicy, jednak z punktu widzenia ochrony tajemnicy przedsiębiorstwa pozostaje bez znaczenia. W związku z powyższym należy uznać, że w analizowanym stanie faktycznym pracodawca powinien wykazać wszelkie okoliczności warunkujące przypisanie byłej pracownicy deliktu na podstawie art. 11 ustawy o zwalczaniu nieuczciwej konkurencji.

Przechodząc do innych interesujących wątków glosowanego orzeczenia, należy odnieść się do zawartego w treści jego uzasadnienia stwierdzenia, że pracownica mogła podjąć działalność konkurencyjną w stosunku do tej prowadzonej przez pracodawcę w związku z brakiem związania umową o zakazie konkurencji. Konstatacja ta zasługuje na pełną aprobatę w odniesieniu do okresu po ustaniu stosunku pracy. Analiza treści art. $101(2) \$ 1$ K.p. w związku z art. 101 (1) $\$ 1$ K.p. prowadzi do wniosku, że ograniczenie pracownika mającego dostęp do szczególnie ważnych informacji, których ujawnienie mogłoby narazić pracodawcę na szkodę w prowadzeniu działalności konkurencyjnej wobec pracodawcy lub świadczenia pracy na rzecz podmiotu prowadzącego taką działalność, warunkowane jest zawarciem odpłatnej umowy o zakazie konkurencji. Odnosząc się natomiast do okresu zatrudnienia pracownicy na stanowisku menadżera operacyjnego $\mathrm{z}$ jednoczesnym sprawowaniem funkcji prokurenta, należy zauważyć, że w przypadku personelu kierowniczego i zarządzającego istnieją podstawy do konstruowania ustawowego zakazu prowadzenia takiej działalności wynikającego wprost $\mathrm{z}$ obowiązku dbałości o dobro zakładu pracy (lojalności). Stanowi on część składową szczególnego obowiązku lojalności osób zajmujących kierownicze stanowiska, ocenianego ze względu na cele i funkcje przedsiębiorstwa ${ }^{19}$. Choć pracownica w czasie trwania

17 Dyrektywa Parlamentu Europejskiego i Rady (UE) 2016/943 z dnia 8 czerwca 2016 r. w sprawie ochrony niejawnego know-how i niejawnych informacji handlowych (tajemnic przedsiębiorstwa) przed ich bezprawnym pozyskaniem, wykorzystaniem i ujawnieniem, tekst jednolity: Dz. Urz. UE. L 157 z 15.6.2016, s. 1.

18 S. Sołtysiński, S. Gogulski, w: Ustawa o zwalczaniu nieuczciwej konkurencji. Komentarz, red. J. Szwaja, 2019 [baza danych Legalis], Komentarz do art. 11, teza 4.

19 T. Kuczyński, Obowiązki pracownika, w: Prawo pracy. Zarys wykładu, red. H. Szurgacz, Z. Kubot, T. Kuczyński, A. Tomanek, Warszawa 2016, s. 179. 
stosunku pracy była związana tego typu zakazem, należy uznać, że nie doszło do jego naruszenia. We wskazanym okresie prowadziła ona bowiem jedynie korespondencję z kontrahentem pracodawcy, dotyczącą utworzenia spółki, która miałaby go zastąpić w zakresie świadczonych usług. Powstanie owego podmiotu i rozpoczęcie przez niego działalności nastąpiło natomiast dopiero po ustaniu stosunku pracy. Należy jednak przychylić się do stanowiska sądu kwalifikującego charakteryzowane zachowanie jako naruszenie wyrażonego w treści art. $100 \$ 2$ pkt 4 K.p. obowiązku lojalności wobec pracodawcy. Na pełną aprobatę zasługuje bowiem pogląd wyrażony przez Sąd Apelacyjny w Krakowie w wyroku z dnia 21 czerwca 2017 r. ${ }^{20}$, w którym stwierdził on, że: „[...] nawet jeśli w niektórych przypadkach umowa o zakazie konkurencji nie zostanie zawarta, pracownika mimo to obowiązuje powinność wynikająca z ogólnego obowiązku dbałości o dobro pracodawcy, zwłaszcza jeżeli dochodzi do zachowania, które może być kwalifikowane w kategoriach nieuczciwej konkurencji”".

W związku z faktem, że do analizowanego stanu faktycznego znajduje zastosowanie art. 11 ustawy o zwalczaniu nieuczciwej konkurencji w brzmieniu sprzed nowelizacji, sąd podjął ponadto kwestię dotyczącą wynikającego z ust. 2 wskazanej jednostki redakcyjnej ograniczenia czasowego ochrony tajemnicy przedsiębiorstwa. Zgodnie ze wskazanym przepisem obowiązek poufności w przypadku osób świadczących pracę na podstawie stosunku pracy lub innego stosunku prawnego obowiązuje przez okres trzech lat od jego ustania, chyba że zawarta między stronami umowa stanowi inaczej albo ustał stan tajemnicy. Sąd stwierdził, że charakteryzowane ograniczenie znajduje zastosowanie jedynie do tych informacji, które pracownik uzyskał w związku z wykonywaniem powierzonych obowiązków. Brak jest natomiast możliwości powołania się na nie w przypadku wiadomości uzyskanych poza zakresem uprawnień i obowiązków, a więc w sytuacji, gdy stosunek pracy ułatwił jedynie wejście w ich posiadanie. Pogląd ten zasługuje na pełną aprobatę. Zawarty $\mathrm{w}$ analizowanym przepisie zwrot „osoba, która świadczyła pracę na podstawie stosunku pracy lub innego stosunku prawnego" należy interpretować jako ograniczenie jego zakresu podmiotowego do osób działających w charakterze strony stosunku zatrudnienia. Przepis ten odnosi się więc wyłącznie do informacji pozyskanych zgodnie z prawem w celu wykonywania obowiązków wynikających ze stosunku pracy lub innego stosunku prawnego, na podstawie którego zatrudniony jest dany podmiot. W odniesieniu do wszelkich informacji pozyskanych bez związku z realizowanym zatrudnieniem wskazane ograniczenia nie znajdą zastosowania, a sytuacja sprawcy czynu powinna podlegać ocenie przez pryzmat reguł 
ogólnych. Należy więc odróżnić kategorię informacji pozyskanych przy wykonywaniu obowiązków od tych uzyskanych jedynie przy okazji ich wykonywania i stosować regulację zawartą w treści art. 11 ust. 2 ustawy o zwalczaniu nieuczciwej konkurencji wyłącznie do pierwszej z nich. W związku z powyższym zasługuje na aprobatę stanowisko sądu wyrażone w uzasadnieniu analizowanego wyroku, zakładające, że inna interpretacja wskazanej regulacji stawiałaby byłych pracowników w wyjątkowo korzystnej sytuacji polegającej na możliwości bezkarnego ujawniania po upływie ustawowego terminu nielegalnie zdobytych informacji stanowiących tajemnice przedsiębiorstwa. Choć po nowelizacji ustawy o zwalczaniu nieuczciwej konkurencji dokonanej w dniu 5 lipca 2018 r. powyższe rozróżnienie zostało zniesione, poczyniona uwaga zachowuje walor praktyczny dla spraw będących $\mathrm{w}$ toku oraz oceny stanów faktycznych zaistniałych przed dniem 4 września 2018 r.

\section{Zakończenie}

Podsumowując powyższe rozważania, należy stwierdzić, że zastosowana przez sąd w analizowanej sprawie konstrukcja zmiany ciężaru dowodu zasługuje na krytyczną ocenę jako nieznajdująca oparcia w obowiązujących przepisach prawach. Dostrzegając okoliczność, że wykazywanie faktu przejęcia przez podmiot nieuprawniony cudzej tajemnicy przedsiębiorstwa przysparza w praktyce wielu trudności, należy jednak uznać, iż przyjęcie proponowanej w rozstrzygnięciu reguły rozkładu ciężaru dowodu nie zasługuje na aprobatę także jako postulat de lege ferenda. Tak korzystne ukształtowanie sytuacji powoda prowadziłoby bowiem niejednokrotnie do wytaczania bezpodstawnych powództw mających na celu wyrządzenie szkody po stronie rozpoczynającego działalność konkurenta rynkowego. Na aprobatę zasługuje natomiast refleksja sądu poświęcona rozgraniczeniu instytucji zakazu konkurencji oraz obowiązku zachowania tajemnicy przedsiębiorstwa, oraz stosowania trzyletniego okresu obowiązywania stanu poufności wyłącznie do informacji pozyskanych w związku z wykonywaniem obowiązków pracowniczych. 


\section{Bibliografia}

Adrych-Brzezińska I., Ciężar dowodu w prawie i procesie cywilnym, Warszawa 2015.

Kodeks cywilny. Komentarz, red. E. Gniewek, P. Machnikowski, 2019 [baza danych Legalis].

Kodeks cywilny. Komentarz, t. 1. Część ogólna, red. A. Kidyba, 2012 [baza danych LEX].

Kodeks postępowania cywilnego, t. 2. Komentarz. Art. 205 (1)-424 (12), red. A. Marciniak, 2019 [baza danych Legalis].

Kuczyński T., Nieuczciwa konkurencja jako kategoria prawa pracy, Przegląd Sądowy 1994, nr 4.

Michalak A., Ochrona tajemnicy przedsiębiorstwa. Zagadnienia cywilnoprawne, Kraków 2006.

Pasqualone D., Intellectual Property: Globespan, Inc v. O’Neil, Berkeley Technology Law Journal 2002, nr 1.

Piasecki K., System dowodów i postępowanie dowodowe w sprawach cywilnych, 2012 [baza danych LEX].

Prawo pracy. Zarys wykładu, red. H. Szurgacz, Z. Kubot, T. Kuczyński, A. Tomanek, Warszawa 2016.

Tyc A., Ciężar dowodu - wokół definicji oraz dopuszczalności umownej regulacji, Zeszyt Studencki Kół Naukowych Wydziału Prawa i Administracji UAM 2012, nr 2.

Ustawa o zwalczaniu nieuczciwej konkurencji. Komentarz, red. J. Szwaja, 2019 [baza danych Legalis].

Ustawa o zwalczaniu nieuczciwej konkurencji. Komentarz, red. M. Sieradzka, M. Zdyb, 2016 [baza danych LEX]. 
